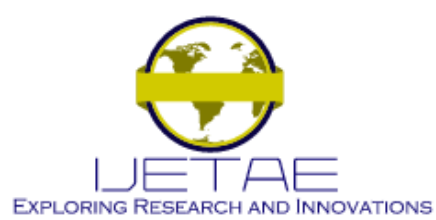

International Journal of Emerging Technology and Advanced Engineering

Website: www.ijetae.com (E-ISSN 2250-2459, Scopus Indexed, ISO 9001:2008 Certified Journal, Volume 11, Issue 05, May 2021)

\title{
IoT Usage On Smart Campus: A Systematic Literature Review
}

\author{
Evaristus Didik Madyatmadja ${ }^{1}$, Tri Rizky Yulia ${ }^{2}$, David Jumpa Malem Sembiring ${ }^{3}$, Sinek Mehuli Br Perangin Angin ${ }^{4}$ \\ ${ }^{1,2}$ Information Systems Department, School of Information Systems, Bina Nusantara University, Jakarta 11480, Indonesia \\ ${ }^{3}$ Teknik Informatika, Institut Teknologi dan Bisnis Indonesia, Indonesia \\ ${ }^{4}$ Akuntansi, Institut Teknologi dan Bisnis Indonesia, Indonesia
}

\begin{abstract}
At present and along with the development of the times, higher education or campuses are increasingly competing with each other, especially in Indonesia. Each campus is competing to improve its quality so that it has a good assessment and can become a World Class University. This is done in various ways, for example, such as providing campus infrastructure that is equipped with adequate technology or combining technology into activities or all processes on campus, this is called the implementation of a smart campus. So that by forming a smart campus, the campus can produce better quality human resources. One form of technological advancement is the emergence of internet technology, the Internet stands for interconnection networking as a communication network connecting between electronic media using the standard IP (Internet Protocol). The internet has many benefits that make it widely used in various industrial sectors, one of which is in the higher education industry. IoT exists as an evolution of the internet as a system that has remote control. IoT is one of the right solutions to support smart campus implementation. The use of IoT on a smart campus can improve campus quality, efficiency and effectiveness. The purpose of this study is to determine the description of IoT, the network technology used and how the implementation can be done on a smart campus.
\end{abstract}

Keywords - Smart Campus; IoT Technology; Systematic Literature Review.

\section{INTRODUCTION}

Currently the world has been faced with increasingly rapid technological developments. technological sophistication without us knowing it is very beneficial in helping every activity or work for humans and their surroundings to be efficient, effective and more leverage [1]. Of the many benefits generated, many industries collaborate technology with humans (HR) in carrying out business processes or activities to make them more efficient and optimal. The emergence of the internet is one proof of technological progress.
Internet stands for interconnection networking as a communication network that connects electronic media using the IP (Internet Protocol) standard [1]. The internet can simplify the process of implementing a system or business process, can save time and costs, can maintain security, etc. With some of the benefits provided by internet technology, making the internet used in almost all fields or layers such as individuals, business, government, and education. All activities or interactions that use the internet are called the Internet of Things (IoT), IoT itself is an evolution of the internet and one of the most frequently developed IoT-based systems is a remote control system [1].

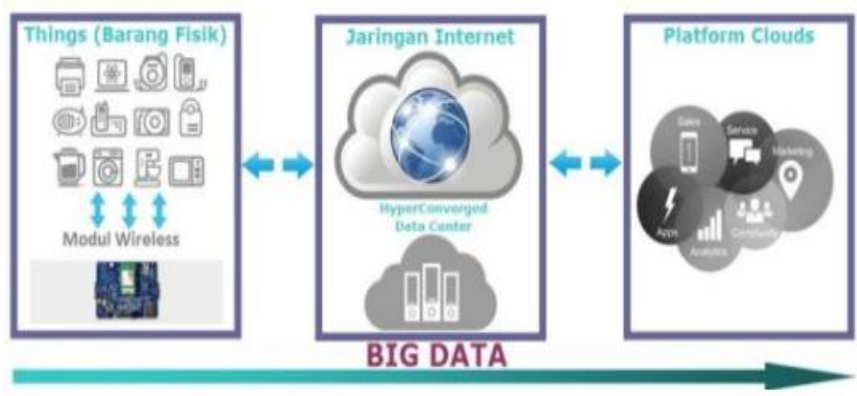

Figure 1: Component of IoT [1]

In general, IoT can work with three main things including things (objects), connectivity (internet network) and clouds (datacenter) [1]. The concept is that objects in the real world will be given QR Code and RFID in order to have a unique identity that can be recognized by the system and data can be represented to the datacenter [1]. The concept of IoT work is with a remote control system of an object. All activities in IOT are to collect correct raw data in an efficient manner and to analyze and process raw data into more valuable information (C. Wang et al., 2013). 


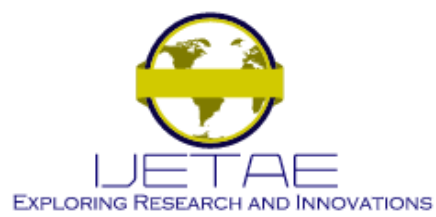

International Journal of Emerging Technology and Advanced Engineering

Website: www.ijetae.com (E-ISSN 2250-2459, Scopus Indexed, ISO 9001:2008 Certified Journal, Volume 11, Issue 05, May 2021)

IoT (Internet of Things) was first introduced by Kevin Ashton when goingmade a presentation to Proctor and Gamble in 1999 [2].

The table below is network technology, there is type of technology and wireless technology in development IoT.

Table I:Network Technology of IoT

\begin{tabular}{|c|c|}
\hline \multicolumn{2}{|c|}{ Network Technology of IoT } \\
\hline Type of Technology & Wireless Technology \\
\hline $\begin{array}{l}\text { Personal Area Network } \\
{[2]}\end{array}$ & Bluetooth [2] \\
\hline $\begin{array}{l}\text { Wireless Local Area } \\
\text { Network [2] }\end{array}$ & Wifi[2] \\
\hline $\begin{array}{l}\text { Cellular Communication } \\
\text { [2] }\end{array}$ & 4G, 3GPP [2] \\
\hline Wide Area Network [2] & LP-WA [2] \\
\hline
\end{tabular}

The quality of a college or university is one of the factors that people pay attention to when choosing a university to continue their education. Not only quality, but there are several other factors to consider such as infrastructure and supporting technology. With the IOT technology, this can be used as a way for campuses or universities to improve service and quality [3]. Especially at this time, advanced countries have implemented IOT technology in supporting lecture activities and business processes on a campus. So that the quality possessed by the campus will also be better [3].

Currently there are still several campuses, especially in Indonesia, which still carry out business processes or activities manually or it can be said that there is still a lack of application of supporting technology on campuses. Some examples of campus activities or activities that are still being carried out manually include:

- Student attendance which is still a signature on the paper

- Search for parking slots manually or there is no full information on parking slots so that students, guests or lecturers experience delays because they take time to find parking

- The student registration process that still has to be done directly on campus, the process of searching

- payment types that are still manual in the canteen or campus tenant area

- Search for books in libraries that are still manual, etc.
This can be used as a benchmark for universities or campuses in Indonesia to have better quality and be able to compete in the current era of globalization. Various campuses in Indonesia are currently competing to improve their quality to become a World Class University which has adequate technological infrastructure.

The solution that can be done is to build a smart campus by utilizing the Internet of Things. Where the implementation of a smart campus is to combine the learning process or lectures with supporting technology such as media devices on campus and will be connected to a computer network [4]. This is done to automate everything that is still manual. If a smart campus with the Internet of Things is successfully implemented and in accordance with the needs of the campus, it will improve the quality of the campus, increase convenience for students, lecturers or staff, make campus management easier and can better support all campus academic activities [4]. So that the campus can have more value and can compete in the future.

The purpose of this study is to provide an overview of IoT architectural designs that can be done in creating smart services or smart buildings on campus. Some examples of services that can be implemented are smart libraries, smart parking, smart classrooms, smart canteen, etc.

\section{BACKGROUND STUDY}

\section{A. Definition Internet of Things}

IoT is a form of innovation from current technological advances. IoT can be run remotely connected to the internet network so that the objects or devices used can interact with each other [4]. IoT (Internet of Things) is useful in supporting the lecture process, campus infrastructure, academic systems, and campus management systems to become easier, more efficient, effective, cost-effective, modern and of high quality [5]. Especially in the current era of globalization, technology is needed in almost every activity or business process. With the rapid development of technology, the use of IoT (Internet of Things) has great potential in the world of education today so that it can produce better quality education and can compete in the global era. 


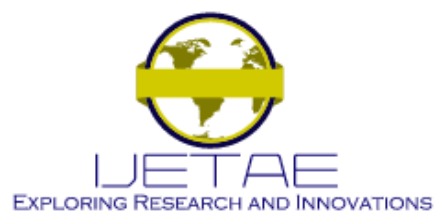

International Journal of Emerging Technology and Advanced Engineering Website: www.ijetae.com (E-ISSN 2250-2459, Scopus Indexed, ISO 9001:2008 Certified Journal, Volume 11, Issue 05, May 2021)

\section{i. Element of IoT Concept that can be used in IoT development}

Table II:Element of IoT

\begin{tabular}{|l|l|}
\hline \multicolumn{1}{|c|}{ Element } & \multicolumn{1}{|c|}{ Description } \\
\hline Sensor & $\begin{array}{l}\text { Sensors function to read or identify } \\
\text { an object that integrates data into } \\
\text { the central system. At present, } \\
\text { especially in the application of IoT, } \\
\text { more use wireless-based wireless } \\
\text { networks [6]. }\end{array}$ \\
\hline Connectivity & $\begin{array}{l}\text { Connectivity is a connection } \\
\text { between devices connected via a } \\
\text { network [6]. }\end{array}$ \\
\hline Artificial & $\begin{array}{l}\text { Artificial Intelligence can be } \\
\text { defined as technology that has the } \\
\text { ability to produce smart services. In } \\
\text { making AI, what needs to be done is } \\
\text { collecting data, building networks, } \\
\text { and developing AI [6]. }\end{array}$ \\
\hline Dashboard & $\begin{array}{l}\text { Dashboard is a user display when } \\
\text { observing activities in real time on } \\
\text { all system devices used [6]. }\end{array}$ \\
\hline
\end{tabular}

\section{ii. $\quad$ The Benefits of Implementing IoT}

There are several benefits of implementing IoT, including:

- By utilizing IoT technology, the benefits provided to quality or services on campus can be more optimal [7]. For example, IoT can connect many objects or devices in a real environment so that electronic devices can interact with each other. In addition, IoT also makes it easier for humans to do work and has more efficient and accurate results.

- The implementation of IoT in an industry relies on internet connectivity networks and supporting technology such as sensors, RFID, to the database center. So that an activity or business process in a company is carried out using a system or technology. This has an impact on human interaction in doing work which is also reduced, so that errors in a job can be more resolved and the data or information captured by the system will also help in making decisions [8].
- When IoT is implemented in an industry, for example on a campus. All administration, activities to business processes are carried out automatically through the system. For example, in the new student registration section, usually the campus will provide a paper form that will be filled out by prospective students. However, when the IoT has been implemented, registration is carried out through an online system. So this indirectly has an impact on reducing paper usage, reducing operational costs incurred by the campus [9].

- IoT can improve services on campus [10]. For example, in the campus library section. Previously, the library department had used student cards as access to the library. With the sophistication of IoT technology, the campus can develop its services, for example by utilizing smartphones, internet and GPS networks to make it easier for library visitors when they want to find the desired book. So that visitors will get directions to the location of the book is located.

\section{B. Definition Smart Campus}

Smart Campus is an implementation of the teaching and learning process or other campus academic activities combined with information technology tools as a support to produce smart campus services, including implementing information technology in activities or business processes on campus [11]. The application of a smart campus is also carried out as a form of campus investment, because the application of technology or systems in campus activities or processes can save more on operational costs, increase efficiency and also effectiveness [12]. This Smart Campus is also carried out as an effort to improve the quality and creativity of students or human resources on campus [12]. This is important to do for several universities in Indonesia, where there are still several universities that are not yet supported by reliable information technology in their infrastructure. Previously, the world's leading universities had implemented smart campuses with modern and sophisticated technology.

$i$. The differences between smart campus networks and traditional campus networks

A smart campus uses multi-network and IoT technology in each of its management, between objects can interact with each other in sending information or data. 


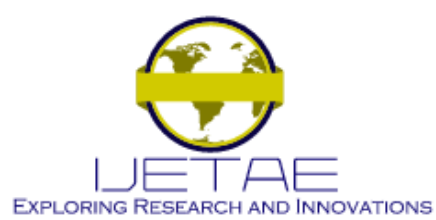

International Journal of Emerging Technology and Advanced Engineering

Website: www.ijetae.com (E-ISSN 2250-2459, Scopus Indexed, ISO 9001:2008 Certified Journal, Volume 11, Issue 05, May 2021)

Meanwhile, campuses that have not implemented a smart campus have a stand-alone system between sections so that there is no integrated central data system [13].

ii. The Part of Smart Campus

The Part of Smart Campus :

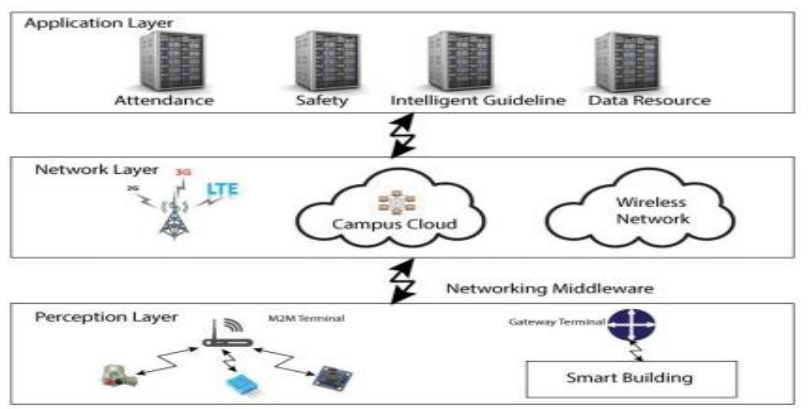

Figure 2: The part of smart campus [13]

- Perception Layer

At this layer, there is data that has been captured on IoT technology devices on the campus [14].

- Network Layer

At this layer, data that has been read by the device will be transferred to a cloud server that is supported by the internet network [14].

- Application layer

Providing services to end users through well- designed and built applications [14].

\section{RESEARCH METHOD}

The research methodology is the method used by researchers in find or collect information from various sources where the data will be or information obtained from several sources can be developed. The method used is literature review, which is a research method that is carried out by analyzing, developing and evaluating information from several reliable scientific paper sources related to similar research topics as reference material in writing scientific papers to be made [15]. Journal searches are carried out through several websites such as Sciencedirect, Emerald, Google Schoolar, Semantic Schoolar, and IEEE.

The sequence of processes carried out in this preparation is literature study, collecting the best theories and topics, theoretical analysis from several sources, developing and compiling research reports.

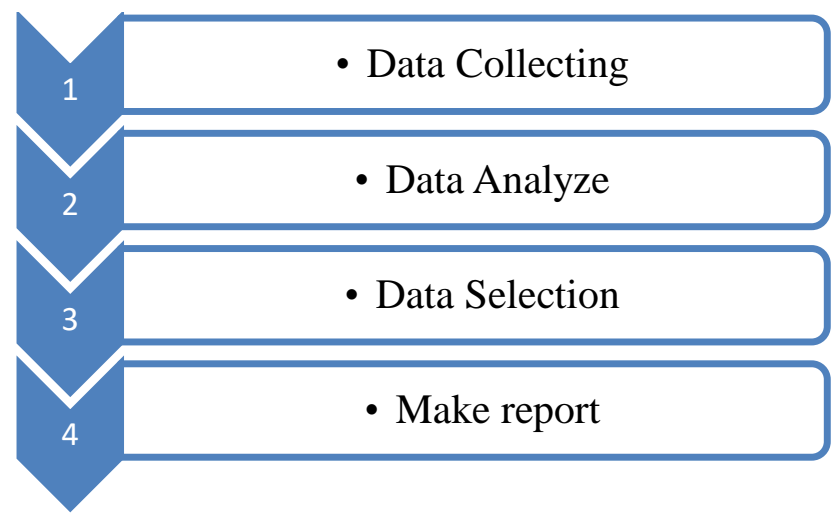

Figure 3 : Process research

\section{RESULT}

\section{A. Study Found}

The first search was carried out using the keywords IoT and Smart Campus on several website sources such as Google Scholar, Science Direct, Emerald, Semantic 'Scholaar, and IEEE. The total paper that was found is 318 from 5 website sources based on the appropriate keyword search results. Furthermore, from the 318 papers found, an analysis will be carried out to select the paper that will be used.

\section{B. Candidate Studies}

Of the 318 papers found, then a paper was selected which had the theory or topic most suitable for the research to be made. After analyzing and selecting, 37 papers were found to be candidates.

C. Selected Studies

Selected papers are suitable and meet the needs of the research topic. The following are the criteria possessed by selected papers:

- Journals published with a span of 2017-2021

- The journal has a core description that refers to a form of smart campus implementation with a combination of IoT technology

- The journal discusses the workflow of implementing IoT technology on campus

- The selected journal is the latest journal so that it has the latest and accurate theory or information

The results of the paper according to some of the needs above are 25 papers. The following is an illustration of a summary of studies found, candidate studies, and selected studies. 


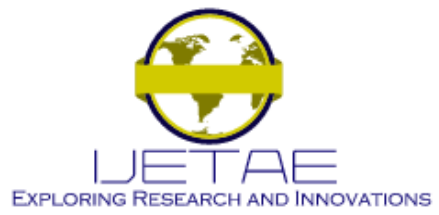

International Journal of Emerging Technology and Advanced Engineering

Website: www.ijetae.com (E-ISSN 2250-2459, Scopus Indexed, ISO 9001:2008 Certified Journal, Volume 11, Issue 05, May 2021)
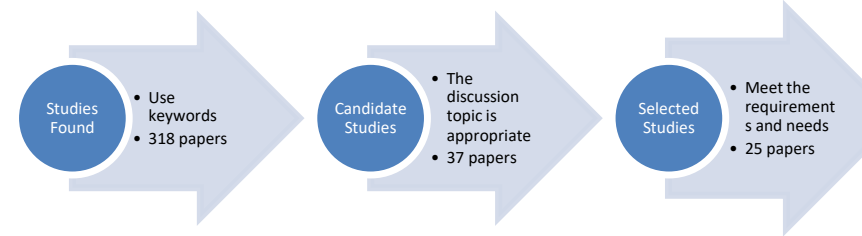

Figure 4 : Strategy for study literature review

And below is a table of the number of papers found

Table III: The number of papaers found

\begin{tabular}{|l|c|c|c|}
\hline \multicolumn{1}{|c|}{ Source } & $\begin{array}{c}\text { Studies } \\
\text { Found }\end{array}$ & $\begin{array}{c}\text { Candidate } \\
\text { Studies }\end{array}$ & $\begin{array}{c}\text { Selected } \\
\text { Studies }\end{array}$ \\
\hline $\begin{array}{l}\text { Science } \\
\text { Direct }\end{array}$ & 80 & 14 & 5 \\
\hline $\begin{array}{l}\text { Google } \\
\text { Scholar }\end{array}$ & 140 & 14 & 14 \\
\hline Emerald & 12 & 5 & 3 \\
\hline $\begin{array}{l}\text { Semantic } \\
\text { Scholar }\end{array}$ & 54 & 3 & 3 \\
\hline IEEE & 32 & 1 & 1 \\
\hline Total & 318 & 37 & 26 \\
\hline
\end{tabular}

\section{Candidate Studies}

Of the 25 papers selected, there were 95 authors, 32 universities and 6 institutions. The locations of existing universities or institutions include the Netherlands, UK, Saudi Arabia, Morocco, France, Greece, Ciprus, Pakistan, India, Japan, UK, Vietnam, Finland, Jamaica, Jordan, Canada, Indonesia, and USA.

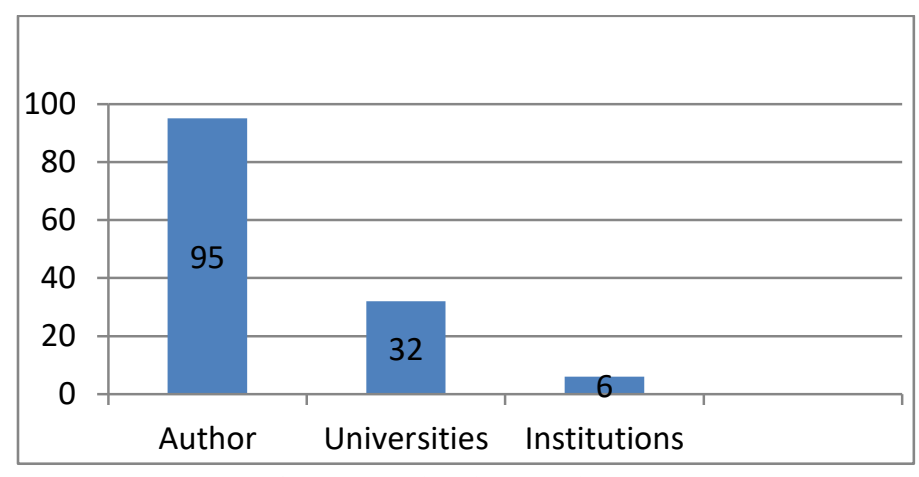

Figure 5 : Author demography

Furthermore, below is a figure of the published years of the 25 selected papers

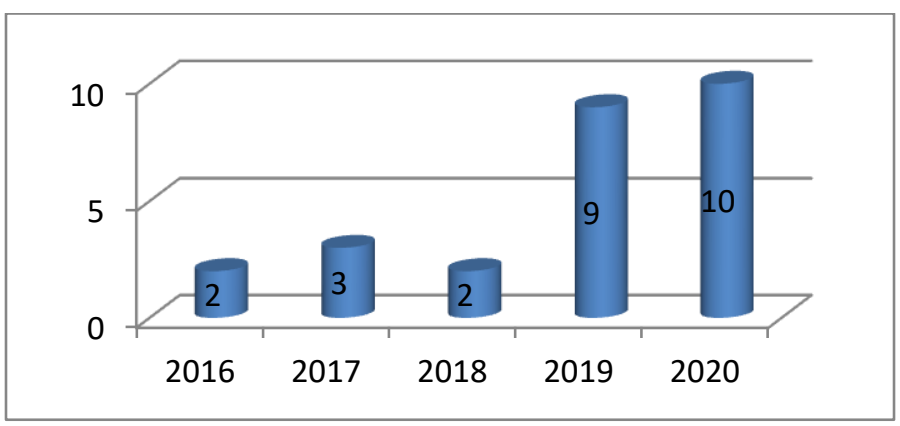

Figure 6 : Publication year

And below is a figure of universities in the country

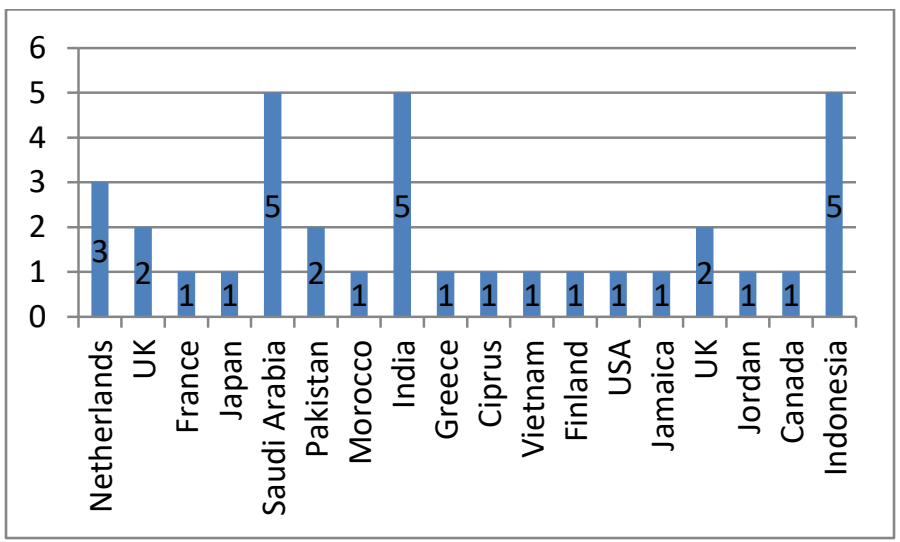

Figure 7 : University in the country 


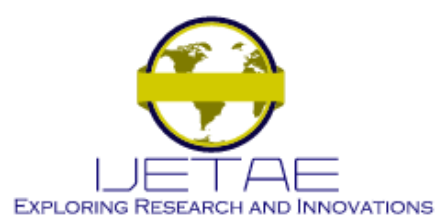

International Journal of Emerging Technology and Advanced Engineering Website: www.ijetae.com (E-ISSN 2250-2459, Scopus Indexed, ISO 9001:2008 Certified Journal, Volume 11, Issue 05, May 2021)

\section{E. Implementation of IoT on Smart Campus}

There are various forms of implementing IoT technology in creating a smart campus, including

\section{i. Smart Learning}

Smart Learning involves students and lecturers in the process of its activities. Smart Learning is built to form a more interactive and collaborative teaching and learning process, besides smart learning can be useful for distance learning [16]. The implementation of smart learning is an effort to improve better learning methods.

\section{ii. Smart Classroom}

Is a form of system that can help the student attendance process so that it does not take time, and of course has a higher accuracy than the regular attendance system using paper. The implementation of smart attendance can also regulate classroom lighting and air conditioners automatically so as to save electricity [17]. In the picture below, there are several objects that are owned, such as Raspberry pi, Arduino Mega, NodeMCU, sensors, and we servers that are connected and interact with each other in sending data and information.

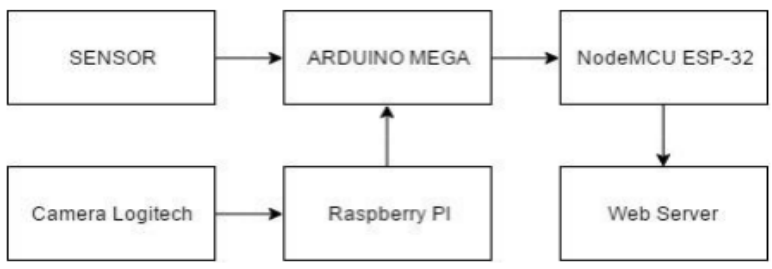

Figure 8 : Objects collaboration for smart classroom

Raspberry Pi, Arduino Mega, NodeMCU, Raspberry will take video via a webcam camera, sent over a network and will be displayed on a web server [17]. Rasperberry pi works with the concept of detecting human faces in the room, if it manages to detect humans in the classroom, Arduino will activate a relay connected to the light to turn it on. The sensor is one of the objects that helps in the attendance system, the camera sensor works to detect faces, data will be captured and compared with a database with similar images and student attendance status will automatically be marked by its presence [18].

\section{iii. $\quad$ Smart Parking}

The smart parking system can make it easy for users when want to park the vehicle, where users don't need to look for one by one parking slot that is still empty.
User can see which parking slot still empty or available via the information board at the parking area where each parking area has sensors to detect vehicles that have been enter or park. This smart parking system uses a mobile phone with internet connection [19]. Where customers can see the status of the parking slot through the application [19]. And for security, the existing smart parking system also uses video surveillance technology to monitor parked vehicles. The way video surveillance works is with the video capture feature on the front end and functions to analyze the monitored image, this system uses an algorithm. When there is a security threat, the monitoring center is immediately alerted [20].

\section{iv. Smart Library}

a. Location guide and book information : The working concept of this system is that all books in the campus library have been recorded in the library application database and in each book there is an identification chip [21]. Furthermore, when library visitors enter the book title, a book identifier code, information, and a map of the book's location will appear in the application. With this identification code, smartphones and books exchange information which is supported by the internet network [21]. Furthermore, the GPS in the application will guide visitors to the location of the book in the library

b. Collection management : There is a system that is of course supported by IoT technology which functions to access and store information related to the number of library books, the number of books borrowed, the identity of the borrower and data on books borrowed, data on late repayments and the amount of fines for each borrower [21]. c. Library entry: This is one of the most important aspects of a campus library. Every visitor who wants to enter the library area must tap student cards on the tapping machine [21]. The machine will read the student identity on the card via an RFID tag, RFID is useful for identifying the identity of visitors [22]. If the card is valid, the library entrance gate will open .

\section{SDN INFRASTRUCTURE FOR IOT SECURITY}

The use of IoT is very beneficial or can support the process of improving campus quality, namely by implementing a smart campus system. However, as the use of the internet grows, the threats to network security are increasing. The security mechanisms that have existed before are such as Firewalls, where the mechanism 


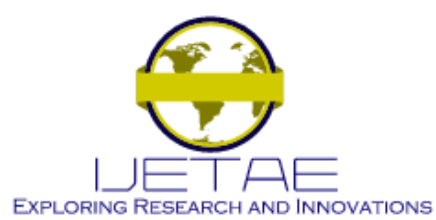

International Journal of Emerging Technology and Advanced Engineering

Website: www.ijetae.com (E-ISSN 2250-2459, Scopus Indexed, ISO 9001:2008 Certified Journal, Volume 11, Issue 05, May 2021)

functions to protect the network from external attacks [22]. However, the more complex the network and architecture used in IoT implementation, a security mechanism that is more suitable for the next generation internet is needed [22]. One of the newest technologies that is suitable for application in IoT network security is SDN (Software Defined Network) [23]. SDN can manage the network as a whole and has a responsive reaction to network security threats.

The SDN architecture has three layers including :

1. Infrastructure layer

2. Control layer

3. Application layer [23].

Here is the SDN domain network concept in security :

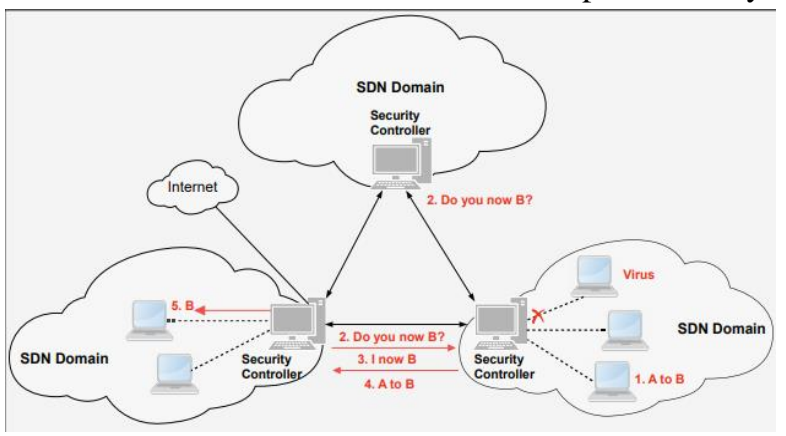

Figure 9 : SDN domain network [23]

SDN will authenticate network devices to protect network resources and furthermore the control layer on SDN will push the appropriate stream entry to software or hardware [23]. Each layer is managed with a different controller and executed with centralized control[24].

\section{v. The Benefits of Implementing Smart Campus with IoT Technology}

- System integration

The result of implementing a smart campus is an integrated system. This matter can make it easier between divisions or units on campus to stay connected terms of exchanging information or data [25].

- Improve Campus Quality

By collaborating technology as a support in various activities campus operations make the campus have smart services so that it is indirectly the quality of the campus has also increased [25].

- Data integration
The concept of smart campus technology is to collect data and collect it centrally so that between divisions or campus units can access same database [26].

- Reduces the risk of human error

By using technology in almost every process or activity, this is impact on reducing the work done by HR manually or it can be said that all processes or activities on campus have already been done automatic in capturing information and providing services [27]. So that errors caused by HR can be more reduced.

- Save Operational Costs

The implementation of a smart campus has an impact on lowering operational costs, an example is like the manual recording process using paper already replaced by the system. So that the campus does not need to buy inner paper a lot. And various other examples.

Table IV:List of IoT implementation results

\begin{tabular}{|c|c|c|}
\hline Number & $\begin{array}{c}\text { The Results of IoT } \\
\text { Service }\end{array}$ & Paper References \\
\hline 1 & Smart Learning & {$[16]$} \\
\hline 2 & Smart Classroom & {$[17],[18]$} \\
\hline 3 & Smart Parking & {$[19],[20]$} \\
\hline 4 & Smart Library & {$[21],[22]$} \\
\hline 5 & IoT Security & {$[22],[23],[24]$} \\
\hline 6 & $\begin{array}{c}\text { Benefits of } \\
\text { Implementing IoT }\end{array}$ & {$[25],[26],[27]$} \\
\hline
\end{tabular}

\section{CONCLUSION}

The use of IoT technology on campus is an effort to improve the quality of the campus both in terms of service and quality of human resources. There are several forms of use of IoT technology in activities or all processes on campus such as implementing smart learning, smart classrooms, smart libraries, smart parking to smart canteen. To secure the IoT technology network, an SDN infrastructure is built to avoid existing attacks. The use of IoT technology in implementing a smart campus can produce several benefits, including data and systems that are integrated with each other, reduce the risk of human 


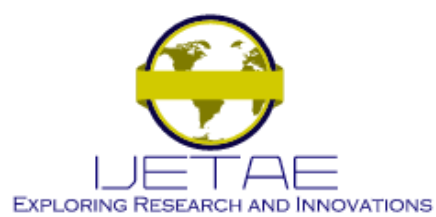

International Journal of Emerging Technology and Advanced Engineering Website: www.ijetae.com (E-ISSN 2250-2459, Scopus Indexed, ISO 9001:2008 Certified Journal, Volume 11, Issue 05, May 2021)

error, save operational costs, and can improve campus quality. With some of the benefits resulting from the use of IoT technology, it is hoped that campuses can produce better, higher quality services and can compete in the era of globalization

\section{References}

[1] Efendi, Y, "Internet of Things (IoT) sistem pengendalian lampu menggunakan raspberry pi berbasis mobile," vol.4, pp. 19-26, 2018.

[2] Shafique, K., Khawaja, B., Sabir, F., Qazi, S., \& Mustaqim, M, "Internet of Things (IoT) for next-generation smart systems: A review of current challenges, future trends and prospects for emerging 5GIoT scenarios," vol. 8, pp. 23022-23040, 2020.

[3] Sari, M., Ciptadi, P., \& Hardyanto, R, "Study of smart campus development using internet of things technology," International Conference on Electrical Engineering, Computer Science and Informatics, 2017.

[4] Torres, B., Rodriguez, J., Bautista, D., \& Guerrero, C, "Smart campus: Trends in cybersecurity and future development," Revista Facultad de Ingenieria, vol. 27, pp. 93-101, 2018.

[5] Yang, A., Li, S., Ren, C., Liu, H., Han, Y., \& Liu, L, "Situational awareness system in the smart campus," vol. 6, pp. 63976-63986, 2018.

[6] Sutjarittham, T., Gharakheili, H., Kanhere, S., \& Sivaraman, V, "Experiences with IoT and AI in a Smart Campus for Optimizing Classroom Usage," IEEE Internet of Things Journal, 2018.

[7] Xu, X., Li, D., Sun, M., Yang, S., Yu, S., Manogaran, G., Mastorakis, G., \& Mavromoustakis, C, "Research on key technologies of smart campus teaching platform based on 5g network," vol. 7, pp. 2066420675, 2019.

[8] Valks, B., Arkeisteijn, M., Koutamanis, A., Alexandra, C., \& Heijer, "Towards a smart campus: supporting campus decisions with Internet of Things applications," Building Recearch and Information, vol. 49, pp. 1-20, 2021.

[9] Dachyar, M., Zagloel, T., \& Saragih, L, "Knowledge growth and development: internet of things (IoT) research, 2006-2018," Heliyon, 2019.

[10]Ikkrissi, G., \& Mazri, T, "A study of smart campus environment and its security attacks," vol. 44, pp. 255-261, 2020.

[11]Valks, B., Arkeisteijn, M., \& Heijer, A, "Smart campus tools 2.0 exploring the use of real-time space use measurement at universities and organizations," Smart Campus Tools 2.0, vol. 37, pp. 961-980, 2019.

[12]Abuarqoub, A., Abusaimeh, H., Hammoudeh, M., Uliyan, D., Hashem, M., Murad, S., Jarrah, M., \& Fayez, F, “A survey on internet of things enabled smart campus applications," International Conference on Future Networks and Distributed Systems (ACM), 2017.

[13] Njah, Y., Pham, C., \& Cheriet, M, "Service and resource aware flow management scheme for an SDN-based smart digital campus environment," vol. 8, pp. 119635-119653, 2020.

[14] Hossain, I., Das, D., \& Rashed, M, "Internet of things based model for smart campus: challenges and limitations," International Conference on Computer, Communication, Chemical, Materials and Electronic Engineering, 2019.
[15] Madyatmadja, E. D , Meyliana., \& Harjanto, P, "Participation to Public e-Service Development: A Systematic Literature Review," Journal of Telecommunication, Electronic and Computer Engineering vol. 8, pp. 139-143.

[16]Veeramanickam, M., \& Mohanapriya, M, "Iot enabled Future smart campus with effective e-learning : I-campus," Journal of Engineering Technology, vol. 3, pp. 81-87, 2016.

[17] Faritha, J., Revathi, R., Suganya, M., \& Gladiss, M, "IoT based cloud integrated smart classroom for smart and a sustainable campus," Procedia Computer Science, pp. 77-81, 2020.

[18] Yuliansyah, H., Corio, D., Yunmar, R., \& Aziz, M, "Smart-Room Technology Implementation Based on internet of things toward smart campus in Institut Teknologi Sumatera," Earth and Environmental Science, 2018.

[19] Ahmed, T, "Student perception on using cell phones as learning tools: Implications for mobile technology usage in Caribbean higher education institutions," An Internation Journal, vol. 4, pp. 25-43, 2020.

[20] Zhou, Z., Yu, H., \& Shi, H, "Optimization of wireless video surveillance system for smart campus based on internet of things," vol, 8, pp. 136434-136448, 2020.

[21] Handayani, F, "Tren Masif Internet of Things (IOT) Di Perpustakaan," Jurnal Ilmu Perpustakaan dan Informasi, vol. 4, pp. 194-209, 2019.

[22] Gawali, S., \& Desmukh, M, "Energy autonomy in iot technology," Energy Procedia, pp. 222-226, 2019.

[23] Olivier, F., Carlos, G., \& Florent, N, "New security architecture for iot network," Procedia Computer Science, pp. 1028-133, 2016.

[24] Raikar, M., Meena, M., \& Mulla, M, "Software defined internet of things using lightweight protocol," pp. 1409-1418, 2020.

[25] Nenonen, S., Wezel, R., \& Niemi, O, "Developing smart service to smart campus," The Scientific Committe of the 10th Nordic Conference on Construction Economics and Organization, vol. 2, pp. 289-295, 2019.

[26] Krishnamurthi, R., Kumar, A., Gopinathan, D., Nayyar, A., \& Qureshi, B, "An overview of iot sensor data processing, fusion, and analysis techniques," 2020.

[27] Ali, Z., Shah, M., Almogren, A., Din, I., Maple, C., \& Khattak, H, "Named data networking for efficient iot-based disaster management in a smart campus," 2020. 